\title{
Zonguldak İli Kesme Çiçek Perakendecilerinin Analizi
}

\author{
Şüheda Basire AKÇA ${ }^{1 *}$, Kübra YAZİCİ ${ }^{2}$, Deniz KARAELMAS ${ }^{1}$ \\ ${ }^{1}$ Zonguldak Bülent Ecevit Üniversitesi, Çaycuma Gıda ve Tarım Meslek Yüksekokulu, Park ve Bahçe Bitkileri \\ Bölümü, 67900, Çaycuma/Zonguldak \\ ${ }^{2}$ Tokat Gaziosmanpaşa Üniversitesi, Ziraat Fakültesi Bahçe Bitkileri Bölümü, 60250, Tokat
}

\section{Öz}

Gelişen sosyo-ekonomik yapıyla birlikte; çevresel ve görsel yaşam bilinci, özellikle süs bitkilerinin üretimine olan taleple birlikte orantılı olarak gün geçtikçe artarak devam etmektedir. Ülkemizin de uygun iklimsel ve coğrafi koşulları, diğer pazar ülkelerine yakınlığı ve ucuz iş gücüne sahip olması gibi nedenler, kesme çiçek üretim alanı ve miktarında önemli artışların ortaya çıkmasını sağlamıştır.

$\mathrm{Bu}$ araştırma, Zonguldak kentinde çiçek perakendecilerinin mevcut yapısını ve kesme çiçek tüketimini belirlemek amacıyla yürütülmüştür. Çalışma, kent merkezi ve ilçelerde bulunan 34 adet çiçek perakendecisi ile yapılan anket çalışması sonucu elde edilen verilere dayanılarak yapılmıştır. Anket çalışması ile perakendecilerin demografik yapısı, çiçekçilerin karşılaştıkları sorunlar, kesme çiçekleri temin ettikleri iller, çiçekleri sunum şekilleri, satış yöntemleri, satış yapılan yerin mülkiyet durumu, dükkân büyüklüğü ve çiçeklerin nakliyesi, en fazla satış yapılan özel günler ve tüketicilerin en çok tercih ettiği kesme çiçek türleri incelenmiştir. Çalışmaya göre en fazla tercih edilen kesme çiçek krizantem olup, kesme çiçekler daha çok buket yapımında kullanılmaktadır. Kesme çiçeklerin temin edildiği illerin başında İzmir ve Yalova gelmektedir. Bunun yanında çiçekler çoğunlukla klimalı soğutucu araçlarla toptancılar tarafından getirilmektedir. Araştırma sonuçlarına göre kesme çiçek perakendecilerinin \% 70.58'sinin erkek, \% 29.42'sinin ise kadın olduğu belirlenmiştir.

Anahtar Kelimeler: Zonguldak, süs bitkisi perakendecisi, kesme çiçek, anket

\section{Analysis of Cut Flower Retailers in Zonguldak Province}

\begin{abstract}
Dependent upon the developing socio-economic structure; environmental and visual awareness of life, especially with the demand for the production of ornamental plants continueto increase day by day. Suitable climatic and geographic conditions of our country, proximity to market countries and cheap labor force have caused significant increases in cut flower production area and quantity.

This study was conducted to determine the current structure of the flower retailers in Zonguldak province and the consumption of cut flowers. The study was carried out based on the data obtained from the survey conducted with 34 flower retailers in the city center and districts. Demographic structure of the retailers, the problems faced by the florists, the provinces where they supply the flowers, the types of flowers, the methods of sales, the status of the place of sale, the size of the place where the sale is made, the size of the shop and the transportation of the flowers, the most preferred special days and the most preferred cut flowers types were inquired. According to the study, the most preferred cut flower is chrysanthemum and cut flowers are mostly used for bouquet making. İzmir and Yalova are the leading cities where cut flowers are supplied. In addition, flowers are mostly brought by whole salers with air-conditioned refrigerated vehicles. According to the research results, $70.58 \%$ of cut flower retailers were male and $29.42 \%$ were female.
\end{abstract}

Keywords: Zonguldak, ornamental plant retailers, cut flower, questionnaire

\footnotetext{
*Sorumlu Yazar (Corresponding Author):

Şüheda Basire AKÇA(Öğr.Gör.);Zonguldak Bülent Ecevit Üniversitesi, Çaycuma Gıda ve

Tarım Meslek Yüksekokulu, Park ve Bahçe Bitkileri Bölümü, 67900,

Çaycuma/Zonguldak. Tel: +90 (372) 643 6601-5090, E-mail: sbasire.akca@ beun.edu.tr

Geliş (Received) : :18.03.2019

Kabul (Accepted) : :18.06.2019

Basım ( Published):15.12.2019
}

ORCID No: 0000-0001-9390-1921 


\section{Giriş}

Süs bitkilerinin geçmişi Osmanlı İmparatorluğuna kadar dayanmakta olup ve bir döneme adı verilecek kadar değerli bulunmuş bir sektördür. Ülkemizde çiçek ve saksılı bitkilerin üretimi 1940'lı yıllarda başlamış olup, günümüze kadar devam etmektedir (Kızılkan, 2016).

Ülkemiz; iklim ve coğrafi koşulları, doğal varlıkları, pazara mesafesi ve istihdam edilebilecek tecrübeli ve yetişmiş eleman açısından süs bitkileri sektöründe önemli avantajlara sahiptir. Her şehirde ve bölgede sektör gelişimi aynı olmamaktadır; nedeni ise sosyo-kültürel sebepler, iklim ve coğrafi koşullardır (Yazici ve Gülgün, 2016;N1emierabetsy ve Holle, 2009; Palma vd., 2011; Cengiz vd., 2017).

Kesme çiçekler ise, üretilebilmesi ve taşıma kolaylı̆̆ı sebebiyle dünyada ve Türkiye'de ticareti en fazla yapılan süs bitkileri grubudur (Gursan, 2002; Kelley vd., 2006; Schimmenti vd., 2013). Dünya tüketiminde önemi artan kesme çiçekler, çiçekli dal olarak hasat edilir ve tanzim edilip tüketim pazarlarına gönderilirler. İklim koşullarına göre kontrollü seralar veya geniş arazilerde yapılan büyük miktardaki üretimler, gelişmekte olan ve az gelişmiş yetiştirici ülkelerin ekonomisine katkı sağlamaktadır (Wijnands, 2005).

Dünyada en fazla kesme çiçek satışının yapıldığı Hollanda mezatında (Royal Flora Holland) 2016 y1lı verilerine göre, toplam 10 milyar 689 milyon 300 bin adet kesme çiçek satışı gerçekleştirildiği belirtilmektedir. Kesme çiçek türleri arasında satışı en fazla gerçekleştirilen tür 3 milyar 362 milyon 600 bin adet dal ile kesme gül olup bunu lale, gerbera ve sprey kasımpatı (krizantem) izlemektedir (Kazaz, 2018).

Türkiye'de ise 2017 yılı verilerine göre 11 bin 748 dekar alanda kesme çiçek üretimi yapılmakta olup en fazla üretim alanına sahip olan tür \% 41.49'luk pay ve 4874 dekar alanla karanfil yer almaktadır. Karanfili \% 17.86 oran ve 2097 dekar alanla kesme gül ve \% 9.66'llk oran ve 1134 dekar alanla gerbera izlemektedir(Kazaz, 2018).

Taze çiçek ve bitkilere olan talep, hem geleneksel tüketim ülkelerinde hem de ekonomik açıdan yeni gelişen ülkelerde artmaya devam etmektedir. Kesme çiçek üretiminin gelişmiş ülkelerde başlamasının sebebi ise en fazla çiçek tüketen ülkeler olmalarıdır. Önceleri kendi ihtiyaçları için üretim yaparken tüketimin artması ve yaygınlaşmasıyla birlikte bilgi birikimlerini teknolojiyle birleştirerek dünyanın önemli kesme çiçek üretici ülkeleri olmuşlardır (Doldur, 2008).

Kesme çiçeklerin pazarlanmasında hasattan satışa kadar olan zaman diliminde tazeliği koruyan bakımlar ve altyapı da oldukça önem arz etmektedir (Batt, 2001). Süs bitkileri perakendecileri üretilen süs bitkilerinin satışa hazırlanması ve tüketicilere ulaştırılmasında önemli rol oynamaktadır. Ayrıca üreticilerden aldıkları ürünleri satabilmek için bulunduğu bölgedeki tüketicilerin zevklerini, tercih ettiği çiçek tür ve çeşitlerini iyi bilmesi gerekmektedir (Aydınşakir vd., 2014).

$\mathrm{Bu}$ araştırmada; Zonguldak kentinde yapılan anket çalışması ile perakendecilerin demografik yapısı, çiçekçilerin karşılaştıkları sorunları, kesme çiçekleri temin ettikleri iller, çiçekleri sunum şekilleri, satış yöntemleri, satış yapılan yerin mülkiyet durumu, dükkân büyüklüğü ve çiçeklerin nakliyesi, en fazla satış yapılan özel günler ve tüketicilerin en çok tercih ettiği kesme çiçek türleri belirlenmeye çalışılmıştır. Bu çalışma sayesinde, Zonguldak ili Çaycuma ilçesinde düşünülen kesme çiçek yetiştiriciliğine katkı sağlamak, uygun tür ve çeşitlerin seçiminde bölgenin taleplerinin göz önüne alınması gereği düşünülmektedir.

\section{Materyal ve Metot}

Araştırma materyalini, Zonguldak ili ve ilçelerinde (Ereğli, Çaycuma, Devrek, Alaplı, Kozlu, Kilimli, Gökçebey) süs bitkileri ticareti yapan çiçekçiler ( 34 adet ) oluşturmaktadır. 2019 yılı Mart ayında çiçekçilere anket uygulaması yapılmıştır. Anket soruları hazırlanırken, Bulut ve ark., (2007) ve Aydınşakir ve ark., (2014)'nın çalışmaları referans alınmıştır. Anket çalışması ile perakendecilerin demografik yapısı, çiçekçilerin karşılaştıkları sorunlar, kesme çiçekleri temin ettikleri iller, çiçekleri sunum şekilleri, satış yöntemleri, satış yapılan yerin mülkiyet durumu, dükkân büyüklügü ve çiçeklerin nakliyesi, en fazla satış yapılan özel günler ve tüketicilerin en çok tercih ettiği kesme çiçek türleri belirlenmeye çalışılmıştır. Anket sonucunda elde edilen veriler SPSS istatistik paket programı ile analiz edilmiştir. 


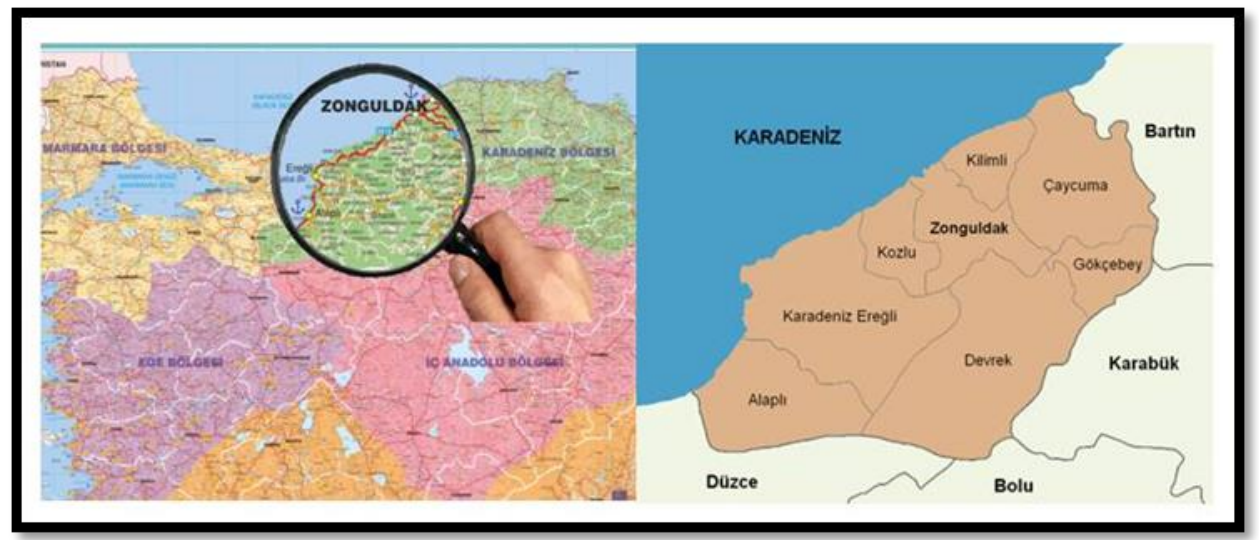

Şekil 1. Zonguldak ili konum haritası

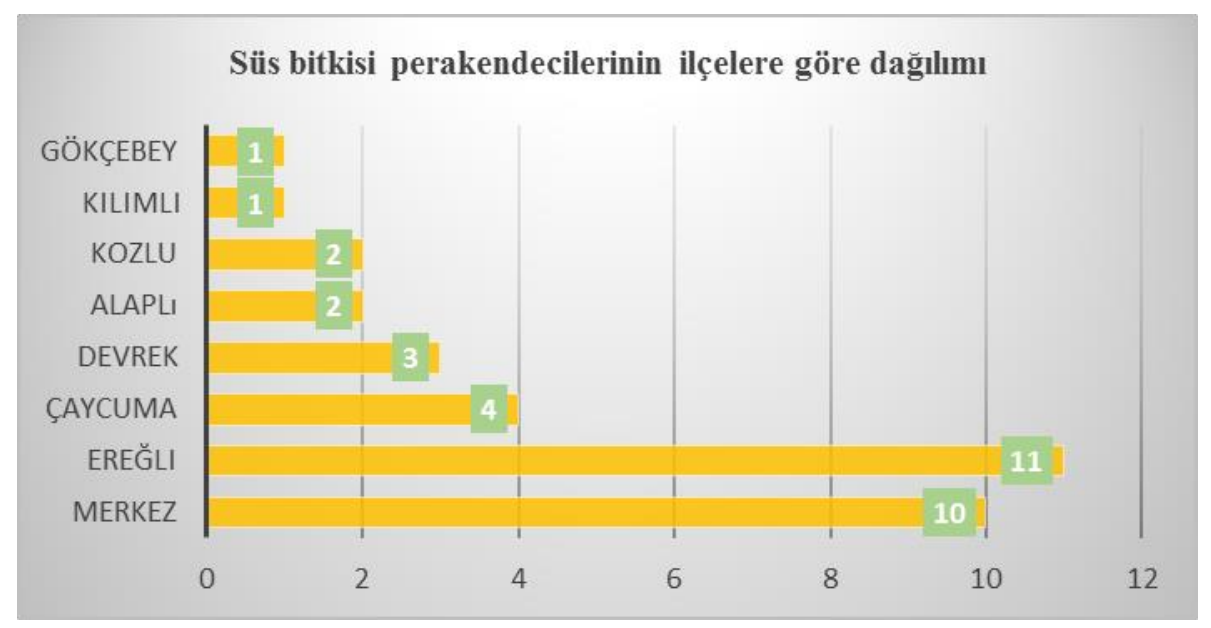

Şekil 2. Süs bitkisi perakendecilerinin ilçelere göre dağılımı

\section{Bulgular ve Tartışma}

Zonguldak ilinde 34 adet işletmeden alınan verilere göre süs bitkileri perakendeciliği yapan kişilerin cinsiyet dağılımları ve eğitim durumları Şekil 3'de gösterilmektedir. Ankete katılan perakendecilerin \% 70.58 'sini erkek, \% 29.42'sini ise kadın nüfusundan oluşmaktadır. Zonguldak ili merkez ve ilçelerinin 2018 yılı verilerine göre toplam nüfusu 599698 olmakla birlikte toplam nüfusun \% 49,58'si erkek, \%50,42'si kadındır (URL-1). Süs bitkileri perakendecilik sektöründeki kadın sayısının toplam nüfus dağılımındaki oranlara göre az olması, cinsiyet faktörünün bu sektörde de etkili olduğunu göstermektedir.

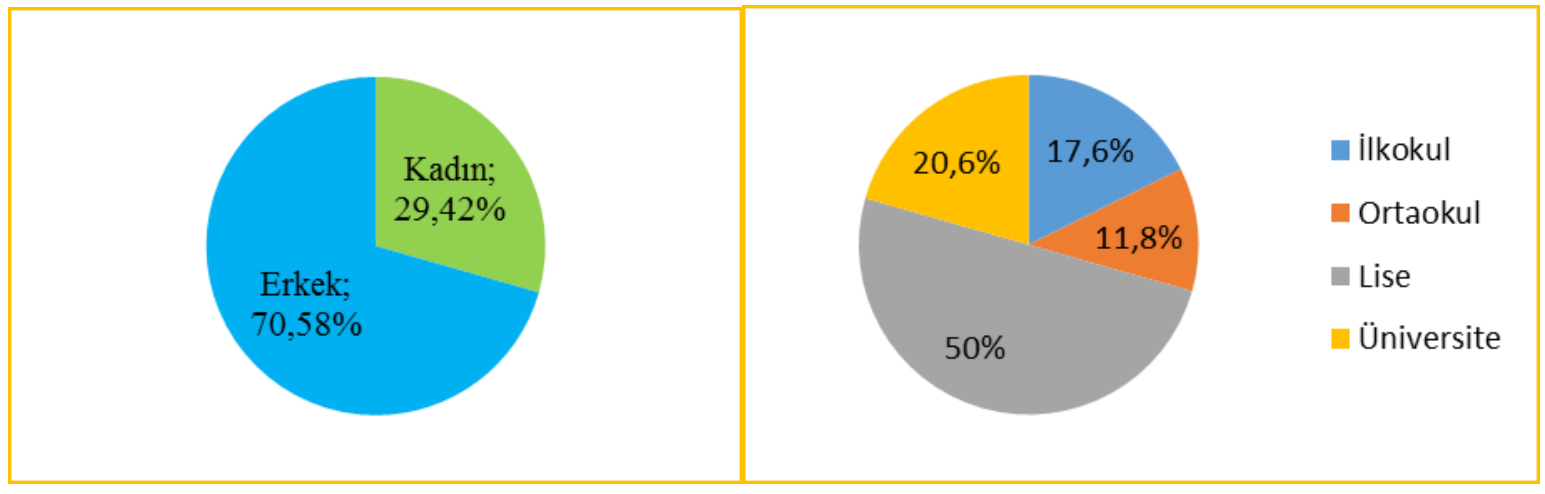

Şekil 3. Ankete katılan perakendecilerin cinsiyet dağılımları ve eğitim durumları 
Ankete katılan süs bitkileri perakendecilerinin eğitim durumlarına bakıldı̆̆ında; \% 17,6'sı ilkokul, \% 11,8'si ortaokul, \% 50'sinin lise, \% 20,6'sının üniversite mezunu olduğu görülmektedir. Anket sonuçları incelendiğinde, kesme çiçek perakendecilerinin yarısının lise mezunu olduğu ve ankete katılan 10 adet bayan perakendeciden 3'ü ilkokul, 5'i lise ve 2'sinin üniversite mezunu olduğu görülmektedir. 24 adet erkek perakendecinin ise 3'ü ilkokul, 4'ü ortaöğretim, 12'si lise ve 5'inin ise üniversite mezunu anlaşılmaktadır (Şekil 3.).

Çizelge 1. Kentteki perakendecilerin deneyim durumları (yıl)

\begin{tabular}{lccccc}
\hline Cinsiyet & $\mathbf{1 - 5}$ yıl & $\mathbf{5 - 1 0}$ yıl & $\mathbf{1 0 - 1 5}$ yıl & $\mathbf{2 5}$ yıl üstü & Toplam \\
\hline Erkek & 6 & 3 & - & 15 & 24 \\
Kadın & 2 & 1 & 3 & 4 & 10 \\
\hline Toplam & 8 & 4 & 3 & 19 & 34 \\
Oran $(\%)$ & 23,5 & 8,8 & 11,7 & 56 & 100 \\
\hline
\end{tabular}

Anket yapılan perakendecilerin deneyim durumları hakkındaki bilgiler Çizelge 1'de verilmektedir. Perakendecilerin \% 23.5'i mesleğini 1-5 yıl aralığından beri yapmakta olduklarını, \%8.8'lik kısmı 5-10 yıl aralığında, \% 11.7'lik kısım 10-15 yıl aralığında ve \% 56'lık kısım ise 25 yıldan daha uzun süredir bu meslekte çalıştıklarını belirtmişlerdir. Süs bitkileri perakendeciliğini 25 yıldan beri yapan işletme sayısı 19 adet olmakla birlikte, ilde uzun yillar öncesine dayanan bir sektör olduğu görülmektedir.

Çizelge 2. Perakendecilerin kentteki dağılımı ve dükkân büyüklüğü $\left(\mathrm{m}^{2}\right)$

\begin{tabular}{lccccc}
\hline Bölge & $<\mathbf{5 0}$ & $\mathbf{5 1 - 1 0 0}$ & $\mathbf{1 0 1 - 2 0 0}$ & $\mathbf{2 0 0}$ & Toplam \\
\hline Merkez & 9 & - & - & 1 & 10 \\
Ereğli & 9 & 2 & - & - & 11 \\
Çaycuma & 2 & 2 & - & - & 4 \\
Devrek & 2 & 1 & - & - & 3 \\
Alaplı & 1 & - & - & 1 & 2 \\
Kozlu & 2 & - & - & - & 2 \\
Kilimli & 1 & - & - & - & 1 \\
Gökçebey & - & - & 1 & - & 1 \\
\hline Toplam & 26 & 5 & 1 & 2 & 34 \\
Oran $(\%)$ & 76.5 & 14.7 & 3 & 5.8 & 100 \\
\hline
\end{tabular}

Anket yapılan perakendecilerin işletmelerin ilçelere göre dükkân büyüklüğü ile ilgili bilgiler Çizelge 2'de verilmektedir. İşletmelerin \% 76,5'inin 50 m² 'den küçük iken, \% 14,7'si 51-100 m² arasında, \%3'ü 101-200 m² arasında, \% 5,8'i ise $200 \mathrm{~m}^{2}$ ' den büyük olduğu belirlenmiştir. Anket sonuçları değerlendirildiğinde genel olarak süs bitkileri perakendecilerinin işletme büyüklükleri $50 \mathrm{~m}^{2}$ den küçük olduğu görülmektedir.

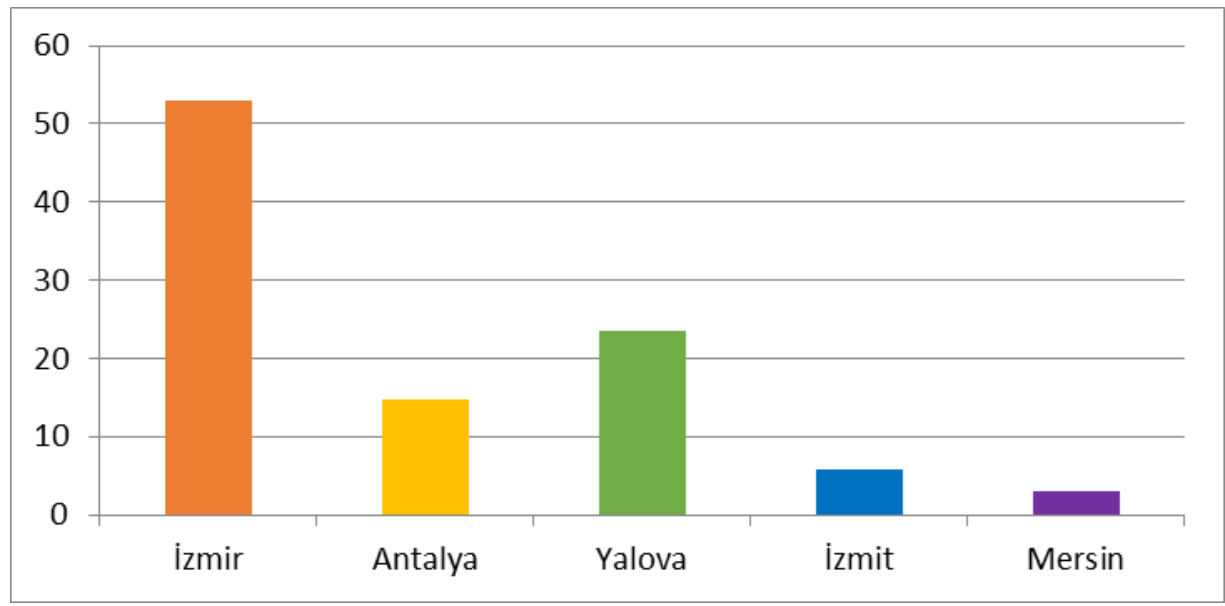

Şekil 4. Kesme çiçeklerin getirildiği iller 
Zonguldak ilindeki süs bitkisi perakendecilerinin kesme çiçekleri tedarik ettiği iller Şekil 4'de gösterilmektedir. Kente getirilen kesme çiçeklerde en fazla tercih edilen il \% 53 ile İzmir olmuştur. İkinci sırayı \% 23,5 pay ile Yalova, sırasıyla bunu \% 14.7 ile Antalya, \% 5.8 ile İzmit ve \% 3 ile Mersin izlemektedir.

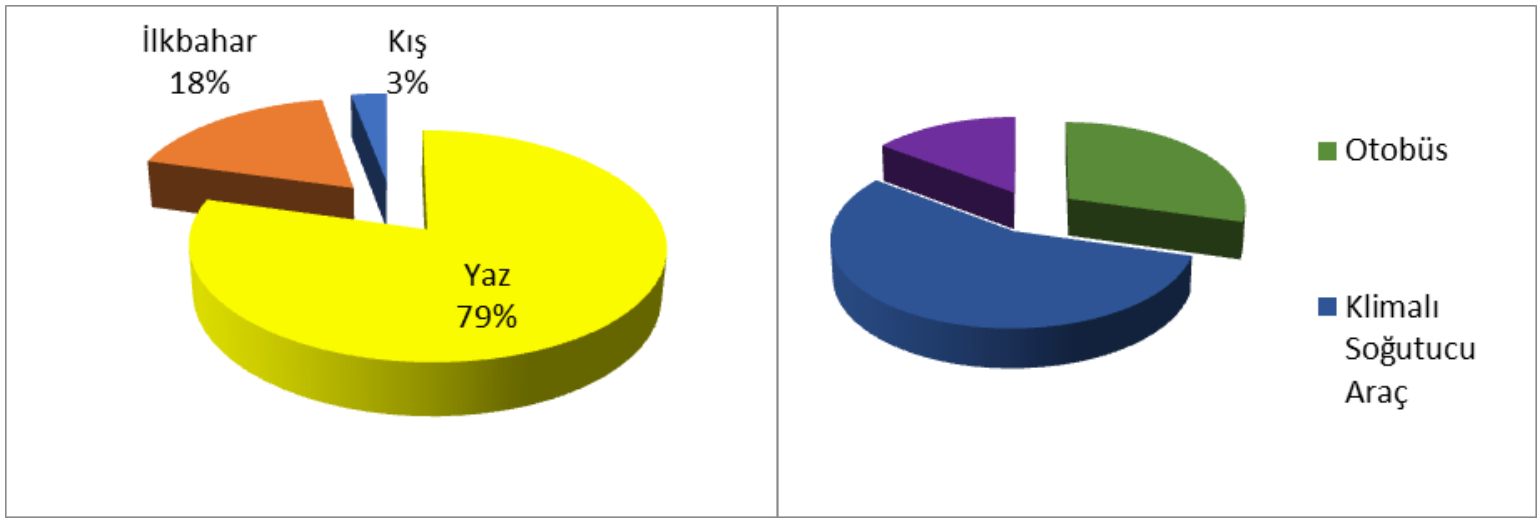

Şekil 5. Kesme çiçeklerin getirildiği mevsim ve kente getirme yolları

Ankete katılan süs bitkisi perakendecilerine yöneltilen diğer sorular ise kesme çiçeklerin en fazla hangi mevsimde getirildiği ve ellerine nasıl ulaştığı olmuştur (Şekil 5). Kesme çiçeklerin en fazla yaz mevsiminde ve aynı zamanda klimalı soğutucu araçlarla (\%56) ile kente ulaştırıldığı anlaşılmaktadır.

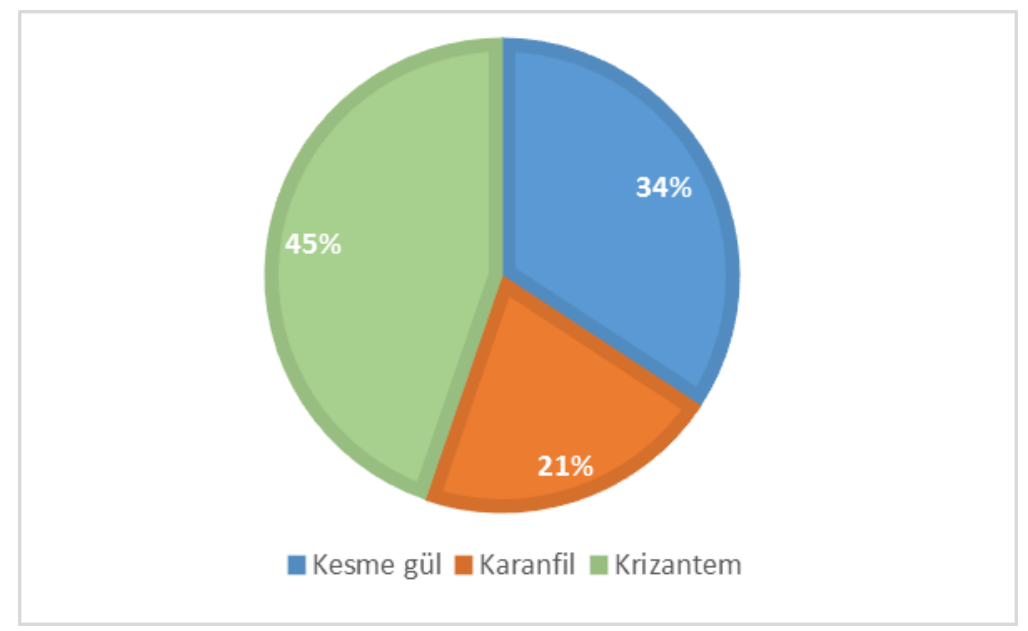

Şekil 6. En çok tercih edilen kesme çiçek türlerinin dağılımı

Zonguldak kentinde süs bitkileri perakendecilerinden halkın en fazla talepte bulunduğu çiçeklerin dağglımı da yapılan anketle belirlenmiştir(Şekil 6). Satışı yapılan kesme çiçekler türlere göre incelendiğinde; en fazla tüketilen kesme çiçeğin krizantem olduğu 2. tercihte kesme gül ve 3. tercihin ise karanfil olduğu ortaya çıkmıştır. Öte yandan, Kazaz(2018)'e göre dünyada en fazla üretilen kesme çiçek türü gül ve Türkiye'de en fazla üretilen kesme çiçek türü ise karanfildir. Bunun yanı sıra gerbera ve papatya kesme çiçek olarak en az tercih edilen kesme çiçekler olmuştur. Nitekim, 34 işletmeden sadece iki işletmede ikinci ve üçüncü tercih olan bu bitkileri ifade ettiğinden dolayı genel dağılıma dahil edilmemişlerdir.

Bulut ve ark.(2007) Erzurum ilinde yaptıkları araştırmada en fazla tercih edilen kesme çiçekleri sırasıyla karanfil, gül, glayöl ve gerbera; Aydınşakir ve ark. (2014)'nın Antalya'da yaptığı benzer çalışma da ise \% 35'ini gül, \% 17'sini gerbera, \%10'u krizantem, \%9'unu gypsophilla ve zambak, \%5'ini karanfil, \% 7'sini mevsimlik çiçekler, \% 4'ünü glayöl ve \%2'sinin ise orkidelerin oluşturduğu bildirilmiştir. 


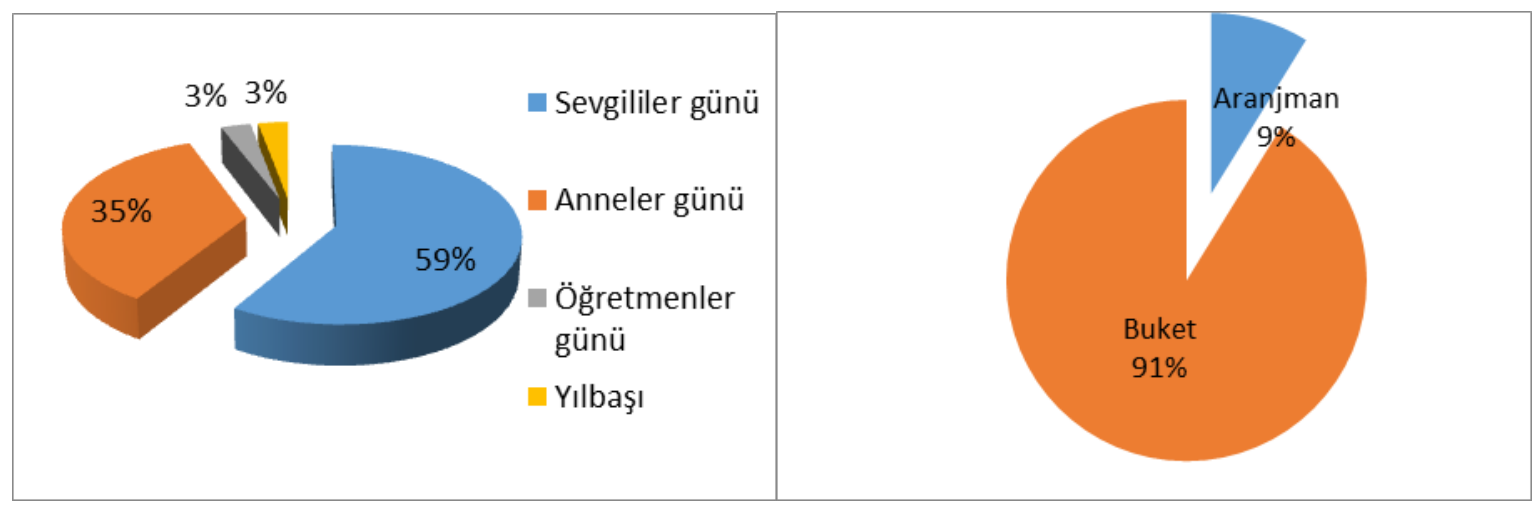

Şekil 7. Kesme çiçek satışının en fazla olduğu özel günler ve perakendecilerin kesme çiçek sunum biçimleri

Perakendeciler yıl içerisinde en fazla kesme çiçek tüketiminin olduğu özel gün sorulduğunda verdikleri yanıtlarda, kesme çiçek satışının en fazla olduğu gün olarak Sevgililer Gününü (\%59) ve sonrasında sırasıyla Anneler Gününü (\%35), Öğretmenler Gününü (\% 3) ve Yılbaşını (\% 3) belirtmişlerdir(Şekil 7). Çiçek sunum şekillerinin nasıl istenildiği sorusuna ise; \% 91'inin buket ve \% 9'nun ise aranjman olarak tüketiciye ulaştığını bildirmişlerdir. Bulut ve ark. (2007)'nın Erzurum'da yaptığı çalışmada ve Aydınşakir ve ark. (2014)'nın Antalya'da yaptığı benzer çalışmalarda kesme çiçeklerin en fazla buket yapımında kullanıldığını belirtilmiştir.

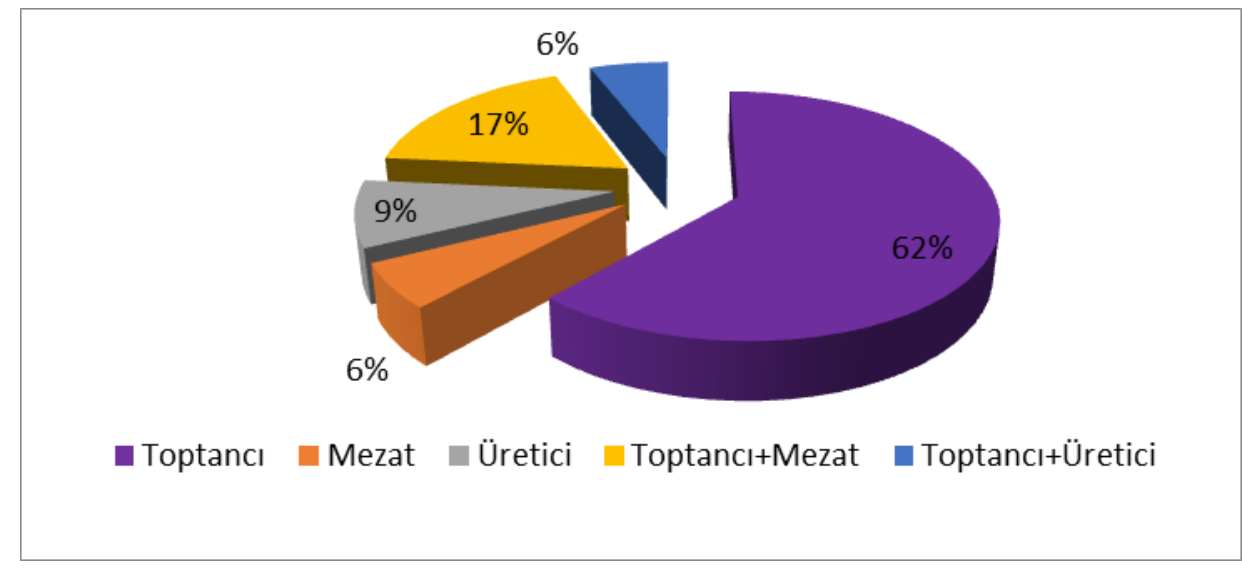

Şekil 8. Perakendecilerin kesme çiçek tedarik yöntemleri

Kentte bulunan perakendecilerin kesme çiçek tedarik yöntemleri ve yüzdelik dağılımları Şekil 8'de gösterilmektedir. Perakendecilerin yaklaşık \% 62'si toptancılardan temin ettiklerini, \% 17'lik pay ise hem toptancı hem de mezattan kesme çiçekleri tedarik ettiklerini belirtmişlerdir.

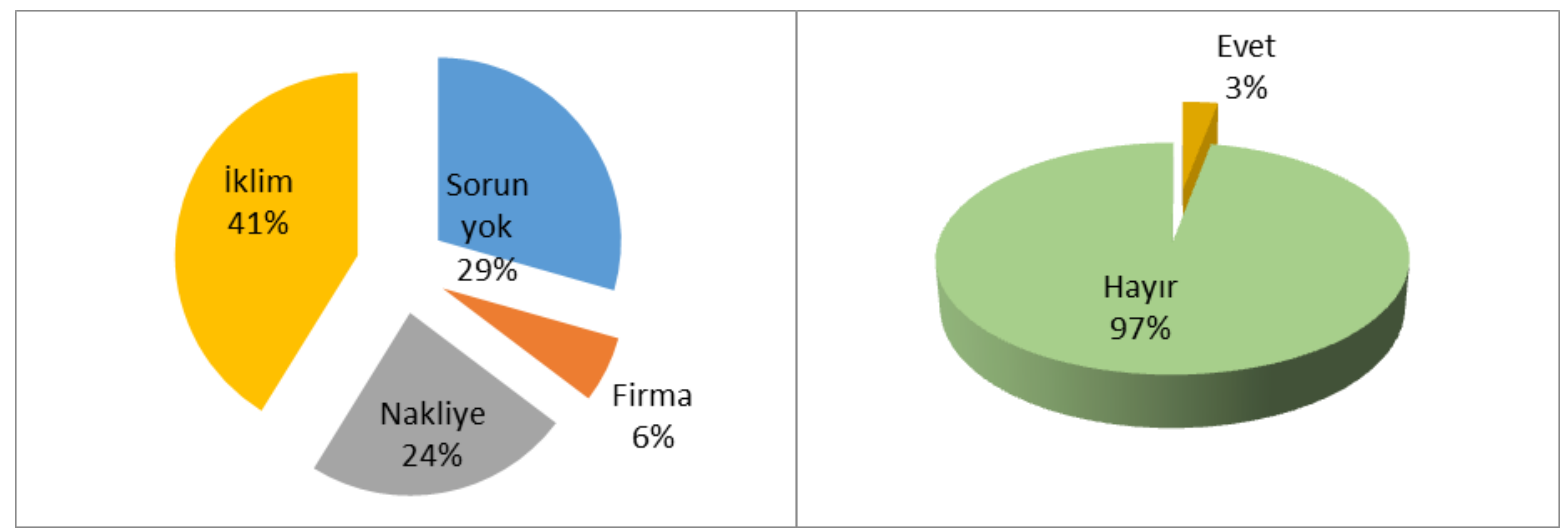

Şekil 9. Kesme çiçek perakendecilerinin karşılaştıkları problemler ve işletmede soğuk hava deposunun varlı̆̆ı

Ankette bulunan sorulardan biri de kesme çiçekleri getirtirken karşılaştıkları problemler olmuştur. Verilen yanıtlar incelendiğinde, karşılaşılan en önemli sorunun iklim koşullarından (\% 41) kaynaklandığı belirlenmiştir. Özellikle 
bu durumun nakil esnasındaki gerekli tedbirlerin alınmaması ile meydana geldiği belirtilmiştir. Zonguldak ilinde bulunan süs bitkileri perakendecilerinin yaklaşık \% 97'si ise soğuk hava deposuna sahip değildir (Şekil 9).

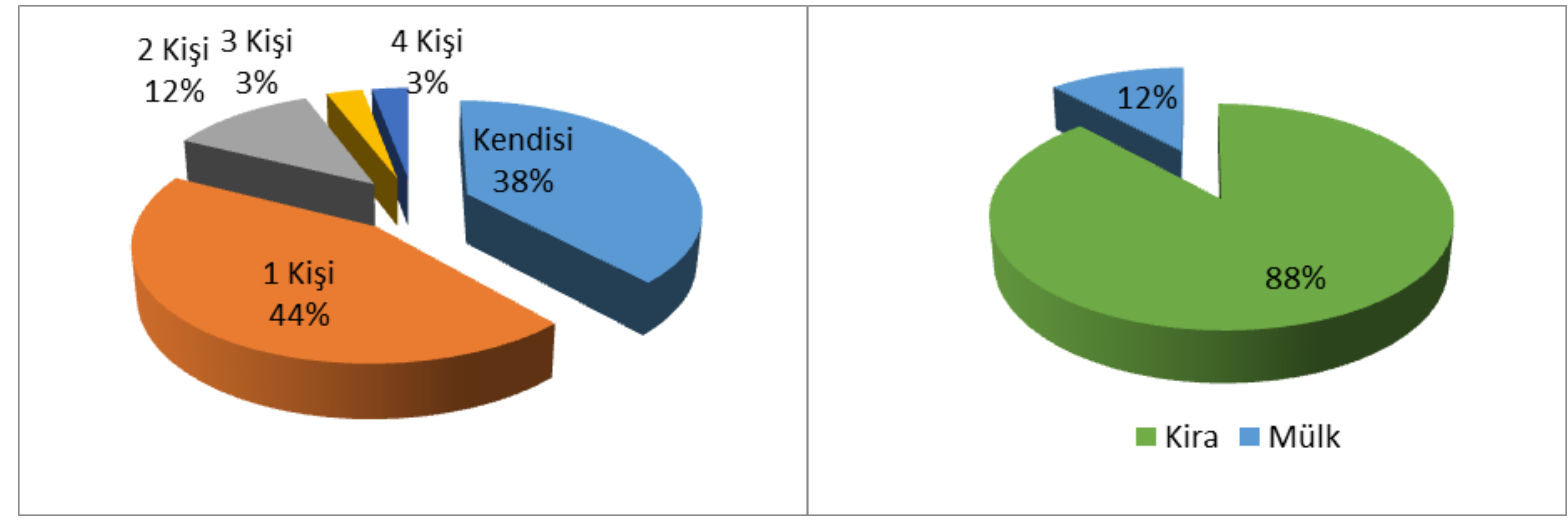

Şekil 10. Kentteki perakendecilerinin personel sayısı ve işletme mülkiyet durumu

Kesme çiçek perakendecilerinde çalışan personel sayısı ve işletme mülkiyet durumu ile ilgili bilgiler Şekil 10'da verilmektedir. Kentte bulunan perakendeciler de çalışan personel sayısı değerlendirildiğinde; yalnızca kendisi çalışan yani personel bulundurmayan işletmelerin oranı \% 38 iken, bir adet personel bulunduranların oranı \% 44, iki adet personel çalıştıranların oranı ise sadece \% 12 olarak belirlenmiştir. Ankete katılan perakendecilerin sadece \% 12'si kendi mülklerinde mesleklerini yaparken, \% 88'i ise işyerine kira ödemektedir. Kentte bulunan kesme çiçek perakendecilerinin büyük bir kısmı küçük ölçekli perakendeci statüsünde bulunmaktadır.

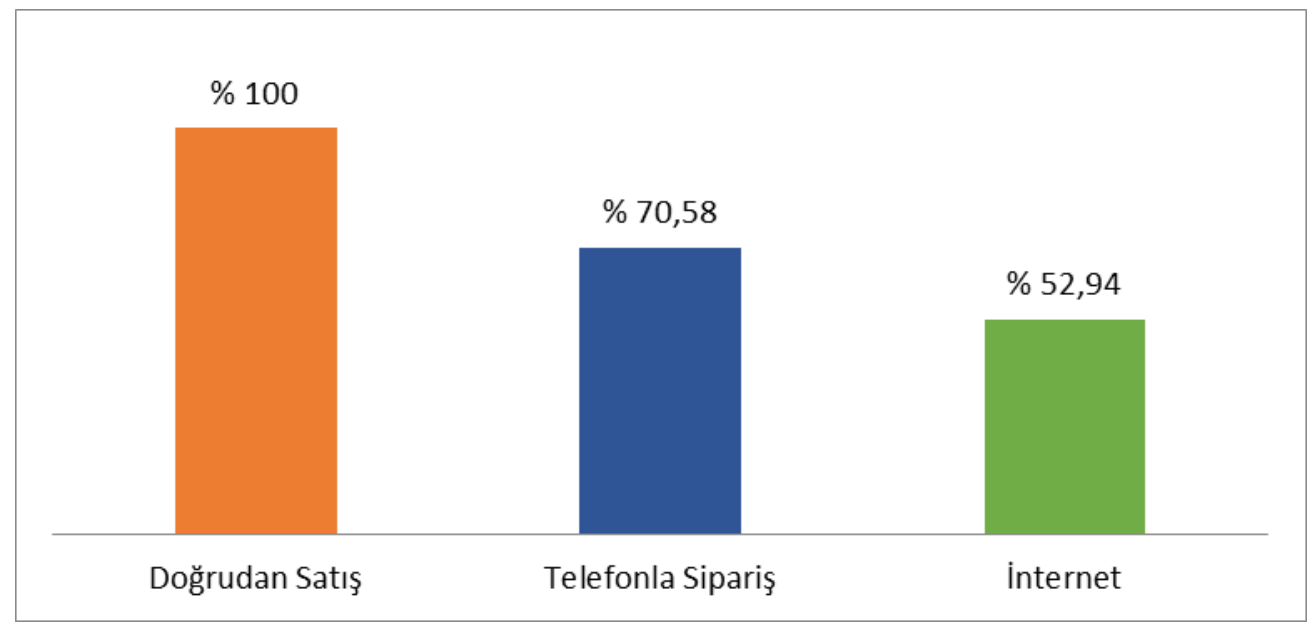

Şekil 11. Kesme çiçek perakendecileri tarafından kullanılan satış yöntemleri

Kentte bulunan ve ankete katılan kesme çiçek perakendecilerinin satış yöntemleri ve dağılımları Şekil 11'de gösterilmektedir. Perakendecilerin tamamı doğrudan satış yaparken, \%70,58'lik kısmı telefon ile sipariş üzerine satış yaptıklarını, \% 52.94'lük bir kısmı ise internetle de satış yaptıklarını belirtmişstir. Bu durum, elektronik ticaretin bölgedeki kesme çiçek sektöründe henüz tam olarak yaygınlaşmadığını göstermektedir.

\section{Sonuç ve Öneriler}

$\mathrm{Bu}$ araştırmada Zonguldak kentinde çiçek perakendecilerinin mevcut yapısı ve kesme çiçek tüketimi ve aynı zamanda karşılaştıkları sorunlar belirlenmiştir. Anket sonuçları değerlendirildiğinde; perakendecilerin demografik yapısı bakımından erkek perakendecilerin kadınlardan daha fazla olduğunu ve perakendecilerin yarısının lise mezunu olduğu ve ankete katılan erkek perakendecilerin daha yüksek eğitim seviyesine sahip olduğu tespit edilmiştir. Sosyo-ekonomik açıdan bakıldığında ise çoğunun sektörde 25 yıldan fazla bir süredir çalıştığı ve işletme mülkiyet durumu ise çoğunlukla kira olduğu belirtilmiştir. Kesme çiçeklerin temin edildiği illerin başında İzmir ve Yalova gelmektedir. Bunun yanı sıra, çiçekler çoğunlukla klimalı soğutucu araçlarla toptancılar tarafından getirilmekte ve kesme çiçekler genel olarak buzdolabında muhafaza edilmektedir. Perakendeciler satışlarını doğrudan, telefon ve internet üzerinden sipariş yöntemiyle gerçekleştirmektedir. Çalışmaya göre 
tüketicilerin eğilimi göz önüne alındığında, en fazla tercih edilen kesme çiçek krizantem olup, kesme çiçekler daha çok buket yapımında kullanılmaktadır.

Batı Karadeniz bölgesinde bulunan Zonguldak ili iklim parametreleri bakımından değerlendirildiğinde; 1lıman Karadeniz iklimin etkisinde olan ilde mevsimler ve gece-gündüz arasında önemli bir sıcaklık farkı görülmemektedir. Bir çok kesme çiçek türünün optimum sıcaklık isteklerinin $18-25^{\circ} \mathrm{C}$ olması ve Zonguldak ilinin de yaz aylarındaki sıcaklık değerlerinin de bu değerlere yakın olması, kaliteli üretim açısından uygun koşullara sahip olduğunu göstermektedir (Kazaz, 2018). Zonguldak ilinin konumu açısından da bir değerlendirme yapıldığında; Ankara ve İstanbul gibi büyükşehirlere yakınlığı ve üretim planlamasına bağlı olarak sadece iç pazara değil ihracata yönelik olarak da yetiştiricilik de yapılabileceği öngörülmektedir. Bununla birlikte; hava, deniz, demiryolu ve karayolu taşımacılığı da teslimat ve tedarik olanakları sağlamaktadır.

Kesme çiçeklerin tüketicilere ulaştırılmasında rol oynayan süs bitkileri perakendeciliği, rekabetin çok yoğun olarak yaşandığı bir faaliyet alanı olması nedeniyle kalite, fiyat, ürün çeşitliliği, ürünün satış yeri, sergileme şekli ve doğru pazarlama stratejisi bakımından oldukça önem taşımaktadır. Bu nedenle, perakendecilerin mevcut durumlarının ve karşılaştıkları sorunların ortaya konularak çözüm yollarının oluşturulması gerekmektedir. Zonguldak ili süs bitkileri perakendecilerinin mevcut durumu göz önüne alınarak ekonomik durumlarının iyileştirilmesi, geleceğe yönelik sağlıklı iş politikaları oluşturulabilmesi ve böylece sektör içerisinde daha iyi konuma ulaşabilmeleri için aşağıdaki öneriler getirilmiştir:

- Süs bitkileri perakendeciliğinde sepet, buket, çelenk ve aranjman gibi çiçek tasarımları oluşturabilme yeteneği oldukça önemlidir. Farklı tasarımlar ile tüketiciye hitap edilmesi tercih edilebilirliği artıracaktır.

- Bölgede çiçek temalı fuar, etkinlik ve ya festivaller ile farkındalık yaratılabilir

- Kent için yerel ve yöresel niteliklerde çiçek tasarım stilleri geliştirilerek; tüm dünyada pazar oluşturulabilir.

- Sağlıklı bir lojistik sisteminin oluşturulmasıyla perakendecilerin rekabet gücünü arttırmada etkili olabilecektir.

- Kesme çiçeklerin muhafazasında optimum koşulları sağlayacak muhafaza yönteminin uygulanması ve hasat sonrası koruyucuların kullanımının yaygınlaştırılması ile ürün kayıpları azaltılabilir.

- Süs bitkileri perakendecileri yıllık cirolarını artırabilmek için reklam, tanıtım, fuarlara katılım ve promosyon gibi tüketicileri cezbedecek faaliyetlerde bulunabilir; satış stratejileri geliştirebilirler.

- Tüketici satın aldığ1 ürün konusunda bilgi almak istediği için süs bitkileri perakendecilerinin çiçek türleri ve bakımları gibi konularda mesleki eğitim alması gerekmektedir.

- İnternet aracılığı ile daha fazla tüketiciye ulaşılabilmesi nedeniyle rekabet edilebilirlik açısından internet satışları artırılmalıdır.

\section{Kaynaklar}

1. Aydınşakir, K., Sayın, B., Çelikyurt, M.A., Karagüzel, Ö. (2014). Antalya İli Kesme Çiçek Perakendeciliğinin Analizi. Akdeniz Üniversitesi Ziraat Fakültesi Dergisi, 27(2): 75-82.3.

2. Batt, P. J. (2001). Strategic lessons to emerge from an analysis of selected flower export nations. Journal of International Food and Agribusiness Marketing, 11(3): 41-54.

3. Bulut, Y., Akpınar, E., Yılmaz, H. (2007). Erzurum Kentinin Kesme Çiçek Tüketim Potansiyelinin Belirlenmesi ve Çözüm Önerileri. Gaziosmanpaşa Üniversitesi, Ziraat Fakültesi Dergisi, 24(2): 7-11.

4. Cengiz, B., Keçecioğlu Dağlı, P., Yiğittekin, S. (2017). Peyzaj Ekonomisi Açısından Peyzaj Ve Süs Bitkileri Fidanlık İşletmelerine Yönelik Sektörel Bir Analiz. Bartın Orman Fakültesi Dergisi, 19 (2), 50-62.

5. Doldur, H. (2008). Kesme Çiçek Üretimi ve Ticareti. İstanbul Üniversitesi, Edebiyat Fakültesi Coğrafya Bölümü, Coğrafya Dergisi, (16): 26-45.

6. Gursan, K. (2002). Türkiye Süs Bitkileri Sektörünün Genel Durumu. II. Ulusal Süs Bitkileri Kongresi. 2224 Ekim 2002. Narenciye ve Seracılık Araştırma Enstitüsü, s: I. Antalya.

7. Kazaz, S. (2018). Kesme Çiçek ve Dış Mekân Süs Bitkileri Yetiştiriciliği Ön Fizibilite Raporu. BAKKA.

8. Kelley, K.M.,Conklin,J.R., Sellmer,J.C.,Bates R.M. (2006).InvasivePlantSpecies: Results of a Consumer Awareness, Knowledge, andExpectationsSurveyConducted in Pennsylvania. Journal of EnvironmentalHorticulture:March 2006, Vol. 24, No. 1, pp. 53-58.

9. Kızılkan, İ. (2016).Türkiye'de Süs Bitkileri Üretim ve Pazarlama Sektörünün Sorunlarl ve Çözüm Önerileri. Ankara Üniversitesi Fen Bilimleri Enstitüsü, Peyzaj Mimarlığı Anabilim Dalı, Yüksek Lisans Tezi, 118 syf.

10. Niemierabetsy, A. X., Holle, V. (2009).Invasive Plant Species and the Ornamental Horticulture Industry. Management of InvasiveWeedspp 167-18 Chapter 9. 
11. PalmaMarco, A.,Hall Charles, R.,CollartAlba, J. (2011).Repeat Buying Behavior for Ornamental Plants: A Consumer Profile, Journal of Food Distribution Research, 42, 2,67-77.

12. Schimmenti, E.,Galati, A., Borsellino, V., Ievoli, C., Lupi, C.,Tinervia, S. (2013).Behaviour of consumers of conventional and organic flowers and ornamental plants in Italy, Hort. Sci. (Prague), Vol. 40, 2013, No. 4: 162-171

13. URL 1-http://www.tuik.gov.tr Erişim tarihi: 05.03.2018.

14. Wijnands, J. H. (2005).Sustainable International Networks in the Flower Industry: Bridging emperical findings and theoretical approaches (No:2). International Society for Horticultural Science.

15. Yazici, K., Gülgün Aslan, B.(2016). TR83 İllerinde Süs Bitkileri Sektörünün Mevcut Durumu ve Geliştirilmesi Üzerine Bir Araştırma. Selçuk Tarım Bilimleri Dergisi, 3(1), 18-24. 